\title{
HIV and hepatitis $C$ virus testing and seropositivity rates in Canadian federal penitentiaries: A critical opportunity for care and prevention
}

\author{
Prithwish De $\mathrm{MHSc}^{1}$, Nancy Connor RN BScN ${ }^{2}$, \\ Françoise Bouchard MD MPH${ }^{2}$, Donald Sutherland MD MSc MCommH ${ }^{1}$
}

P De, N Connor, F Bouchard, D Sutherland. HIV and hepatitis $\mathrm{C}$ virus testing and seropositivity rates in Canadian federal penitentiaries: A critical opportunity for care and prevention. Can J Infect Dis Med Microbiol 2004;15(4):221-225.

BACKGROUND: Incarcerated persons experience high rates of $\mathrm{HIV}$ and hepatitis $\mathrm{C}$ virus (HCV) infection, but little is known about the burden of these bloodborne viruses among federal penitentiary inmates in Canada.

OBJECTIVES: The present study investigates rates of testing and seropositivity for HIV and HCV among inmates in all 53 Canadian federal penitentiaries.

METHODS: A cross-sectional design using surveillance data on voluntary HIV and HCV antibody testing in 2002 were applied to estimate the rate of testing uptake and the rate of incident seropositive tests among new admissions to federal penitentiaries and resident inmates. Rates of testing and infection were further examined by sex and region. Seroprevalence of HIV and HCV was estimated from the number of cumulative positive tests to year-end.

RESULTS: Of 7670 new admissions during 2002, 30\% were tested for HIV and HCV. Test seropositivity rates in this group were $0.7 \%$ for HIV and 10\% for HCV. Of the 12,426 resident inmates, $28 \%$ were tested for HIV and $27 \%$ for HCV. Seropositivity rates in this group were $0.3 \%$ for HIV and $7 \%$ for HCV. Seroprevalence rates at yearend for 2002 were $2.0 \%$ for HIV and $26 \%$ for HCV and were substantially higher among women offenders (HIV: $3.7 \%$ of women, $1.9 \%$ of men; HCV: $34 \%$ of women, $26 \%$ of men). Variations in testing uptake and test seropositivity were observed across regions.

CONCLUSIONS: The present study underscores the value of continued monitoring and evaluation of trends in HIV and HCV infection, which remain prevalent in federal penitentiaries. Higher rates of testing are warranted for at-risk inmates to improve early detection of infection and provide infected inmates with timely care and treatment. For those who remain free of infection, testing can provide the additional benefits of exposing inmates to health counselling and for the reinforcement of prevention messages. The period of incarceration is also a critical opportunity to link inmates with outside resources in preparation for release to the community.

Key Words: Canada; Hepatitis C; HIV; Injection drug use; Prison; Testing
Tests de dépistage du VIH et de l'hépatite $\mathrm{C}$ et taux de séropositivité dans les pénitenciers fédéraux au Canada : excellente occasion de soins et de prévention

CONTEXTE : Les personnes incarcérées connaissent des taux élevés d'infection à VIH et à VHC (virus de l'hépatite C), mais on en sait bien peu sur l'ampleur du problème au sein de la population carcérale, dans les pénitenciers fédéraux, au Canada.

OBJECTIF : Étudier les taux de dépistage et de séropositivité à l'égard du VIH et du VHC parmi les prisonniers dans les 53 pénitenciers fédéraux au Canada.

MÉTHODE : Un modèle d'étude transversale fondé sur des données de surveillance recueillies à partir de tests volontaires de détection des anticorps anti-VIH et anti-VHC en 2002 a servi à estimer le taux de participation aux tests de dépistage et le taux de séropositivité parmi les nouveaux prisonniers et les détenus contemporains dans les pénitenciers fédéraux. Ces taux ont par la suite été examinés selon le sexe et par région. Quant à la séroprévalence du VIH et du VHC, elle a été évaluée à partir du nombre total de tests positifs à la fin de l'année.

RÉSULTATS : Des 7670 nouveaux prisonniers admis en 2002, 30 \% ont subi un test de dépistage du VIH et du VHC; les taux de séropositivité ont atteint $0,7 \%$ pour le $\mathrm{VIH}$ et $10 \%$ pour le VHC. Des 12426 détenus contemporains, $28 \%$ et $27 \%$ ont subi des tests de dépistage du VIH et du VHC respectivement; les taux de séropositivité ont atteint $0,3 \%$ et $7 \%$ pour le VIH et le VHC respectivement. Les taux de séroprévalence à la fin de l'année 2002 se sont établis à 2,0 \% pour le VIH et à $26 \%$ pour le VHC, et ils était sensiblement plus élevés chez les femmes (VIH : femmes : 3,7\%; hommes : $1,9 \%$ et VHC : femmes : $34 \%$; hommes : $26 \%$ ). Des écarts quant aux taux de participation et à la séropositivité ont été observés entre les régions.

CONCLUSIONS : La présente étude fait ressortir l'importance de la surveillance continue du VIH et du VHC et de l'évaluation des tendances en la matière, ces infections étant fréquentes dans les pénitenciers fédéraux et dans certains sous-groupes de la population carcérale. Il est justifié d'effectuer plus de tests de dépistage auprès des prisonniers à risque pour améliorer la détection précoce de ces maladies et fournir des soins et des traitements en temps opportun. Pour ceux qui ne sont pas infectés, les tests de dépistage sont une bonne occasion de recevoir des conseils sur la santé et de se voir rappeler des messages de prévention. De plus, la phase d'incarcération est une période cruciale pour faire connaître aux prisonniers les ressources extérieures en vue de leur libération dans la collectivité.

\footnotetext{
${ }^{1}$ Centre for Infectious Disease Prevention and Control, Health Canada; ${ }^{2}$ Health Services Branch, Correctional Service of Canada Correspondence: Prithwish De, Department of Epidemiology and Biostatistics, McGill University, 1020 Pine Avenue West, Montreal, Quebec

H3A 1A2. Telephone 514-528-2400, fax 514-528-2452, e-mail Prithwish.De@mail.mcgill.ca
}

Received for publication December 15, 2003. Accepted June 14, 2004 
C orrectional facilities worldwide are important settings in the campaign against HIV and hepatitis $\mathrm{C}$ virus (HCV) because incarcerated individuals experience a disproportionate number of these infections compared with the general population $(1,2)$. Persons admitted to correctional facilities often have a history of injection drug use and high-risk sexual activity (2-8), both of which are risk factors for HIV and HCV infection. Such risk behaviours often continue during incarceration $(9,10)$, along with other risk activities for potential disease transmission such as tattooing (8). Because offenders may enter the correctional system already infected, correctional health care assumes the responsibility of caring for those infected and preventing the transmission of disease to uninfected inmates. With most offenders eventually returning to the community, the correctional setting also presents a critical opportunity to identify infected persons and link these inmates with community resources in preparation for their release.

In 1999, the estimated Canadian rates of HIV and HCV infection in the general population were $0.1 \%$ and $0.8 \%$, respectively $(11,12)$. Approximately $34 \%$ of newly reported HIV cases and $63 \%$ of newly reported HCV cases are attributed to injection drug use $(11,12)$. Previous studies have indicated that the prevalence of bloodborne infections among prison inmates varies according to the number of incarcerated injection drug users and the prevalence of risk behaviours in prison such as needle and paraphernalia sharing $(1,2,4,5,8)$. Engaging in risk behaviours by inmates, in turn, are a function of the frequency and history of incarceration, length of time incarcerated, history of drug use and the availability of prevention programs offered in prison $(9,13,14)$.

To date, there are limited data regarding the burden of HIV and HCV infection in Canadian correctional facilities. Better knowledge about trends in testing and infection rates would help formulate more novel approaches to preventing infection transmission, and to planning programs for disease management. To this end, the objective of the present study was to investigate the system-wide patterns of testing and seropositivity for HIV and HCV infection among inmates of Canadian federal penitentiaries.

\section{METHODS}

\section{Study population}

The Correctional Service of Canada is the federal government body responsible for administering correctional sentences of two or more years. The 53 federal correctional facilities in five regions across Canada include minimum, medium, maximum and multilevel security institutions. The inmate population at any point in time is variable because approximately 7000 offenders are admitted and similar numbers are released or paroled each year. The resident population at year-end represents the culmination of new admissions and releases during the year and provides a reasonable estimate of the total inmate population. For the present study, the population at risk of infection was derived by taking into account the following exclusions: female inmates housed in men only institutions, for whom surveillance data were unavailable (18\% of female inmate population); federal inmates residing in provincial correctional facilities who are not enumerated by the Correctional Service of Canada surveillance system; and offenders with documented HIV or HCV serostatus before entry. The exclusion criteria are believed to have minimal impact on the results because a representative sample of inmates is retained. Thus, the study populations consisted of 12,426 (of 12,505 ) resident inmates on December 31, 2002 and 7670 offenders newly admitted between January 1, 2002 and December 31, 2002.

\section{HIV and HCV testing}

Upon admission, at-risk offenders are offered informed, voluntary testing for HIV and HCV as part of an initial health assessment. Testing is also offered to inmates throughout their federal sentence and is routinely performed when clinically indicated. HIV antibody testing is carried out using enzyme immunoassay and a confirmatory Western blot for positive tests. HCV antibody testing is performed using enzyme immunoassay and positive tests are verified by confirmatory recombinant immunoblot assay. All tests are accompanied by pre- and post-test counselling, client-centred education on risk reduction, and appropriate treatment and care.

\section{Data source}

From January 2000, a system-wide surveillance system using standardized case definitions has been in place for monitoring HIV and HCV. Monthly surveillance reports are submitted by institutional health units, but unfortunatelt, do not currently differentiate between acute and chronic cases of HCV infection, nor between HIV and AIDS cases. The electronic surveillance database was used to extract the aggregate number of new positive antibody test results and total number of tests performed, stratified by incarceration status (new admission or resident inmate); the number of HIV - and HCV-positive inmates at admission; and the number of HIV- and HCV-positive inmates who died or were released during the study period.

\section{Variables and analysis}

Offenders were classified as either a new admission, if they were in custody for less than six weeks, or as a resident inmate. The main outcome measures were testing uptake and seropositivity for HIV and HCV among new admissions and resident inmates. The testing uptake rate was defined as the proportion of inmates who underwent voluntary testing. The seropositivity rate refers to the proportion of positive tests among those tested. The cumulative number of seropositive tests minus the number of seropositive inmate deaths and releases was used to calculate the seroprevalence rate (with 95\% CI) at year-end. Testing uptake and seropositivity rates were examined for different Correctional Service of Canada regions and were compared according to sex using $\chi^{2}$ test and Fisher's exact test for counts less than five. All tests were twotailed and considered significant at $\mathrm{P} \leq 0.05$.

\section{RESULTS}

\section{Testing uptake and seropositivity for HIV}

Overall, testing uptake rates for HIV were similar among new admissions and resident inmates $(30.1 \%$ versus $28.2 \%$, respectively). However, within each group, a higher proportion of women than men underwent testing (Table 1). A significant difference in testing uptake between female and male offenders was observed at admission, where the proportion of women accepting HIV testing was nearly double that of men.

Of the 27 inmates diagnosed with positive HIV test results and reported during 2002, 15 (56\%) were recorded among new admissions. Seropositive tests among new admissions represented $0.7 \%$ of all newly admitted male and female offenders. Seropositivity in resident inmates was lower than in new 


\begin{tabular}{|c|c|c|c|c|c|c|c|c|c|c|}
\hline & \multicolumn{3}{|c|}{$\begin{array}{c}\text { Men } \\
\mathrm{n}=7,285 \text { new admissions } \\
\mathrm{n}=12,079 \text { resident inmates }\end{array}$} & \multicolumn{3}{|c|}{$\begin{array}{c}\text { Women } \\
\mathrm{n}=385 \text { new admissions } \\
\mathrm{n}=347 \text { resident inmates }\end{array}$} & \multicolumn{3}{|c|}{$\begin{array}{c}\text { Total } \\
n=7,670 \text { new admissions } \\
n=12,426 \text { resident inmates }\end{array}$} & \multirow[b]{2}{*}{$P^{*}$} \\
\hline & $\mathbf{n}$ & $\%$ & $95 \% \mathrm{Cl}$ & $\mathbf{n}$ & $\%$ & $95 \% \mathrm{Cl}$ & $\mathbf{n}$ & $\%$ & $95 \% \mathrm{Cl}$ & \\
\hline \multicolumn{11}{|l|}{ Antibody tests performed } \\
\hline New admissions ${ }^{\dagger}$ & 2113 & 29.0 & - & 192 & 49.9 & - & 2305 & 30.1 & - & $<0.0001$ \\
\hline General population $\ddagger$ & 3392 & 28.1 & - & 108 & 31.1 & - & 3500 & 28.2 & - & 0.21 \\
\hline General population & 11 & 0.3 & - & 1 & 0.9 & - & 12 & 0.3 & - & 0.31 \\
\hline Seroprevalence & 235 & 1.9 & $1.7-2.2$ & 13 & 3.7 & $2.2-6.3$ & 248 & 2.0 & $1.8-2.3$ & 0.02 \\
\hline \multicolumn{11}{|l|}{$\mathrm{HCV}$} \\
\hline \multicolumn{11}{|l|}{ Antibody tests performed } \\
\hline New admissions ${ }^{\dagger}$ & 2121 & 29.1 & - & 186 & 48.3 & - & 2307 & 30.1 & - & $<0.0001$ \\
\hline Seroprevalence & 3123 & 25.9 & $25.1-26.6$ & 118 & 34.0 & $29.2-39.2$ & 3241 & 26.1 & $25.3-26.9$ & 0.0007 \\
\hline
\end{tabular}

${ }^{*} P$ value associated with $\chi^{2}$ or Fisher's exact test comparing male and female inmates; ${ }^{\dagger}$ New admissions comprise all new warrants of committal, recidivists, revocations, transfers and exchanges of service with provincial and foreign correctional institutions; ¥Resident inmates include temporary detainees

admissions and differed substantially between men and women.

At year-end, HIV seroprevalence was estimated to be $2.0 \%$, with $3.7 \%$ of women and $1.9 \%$ of men reported as being HIVpositive (Table 1). The proportion of HIV-positive inmates differed by region, ranging from $1.4 \%$ in the Ontario and Atlantic regions to $2.8 \%$ in the Quebec region (Figure 1).

Testing uptake and seropositivity for $\mathrm{HCV}$

The testing uptake rate for $\mathrm{HCV}$ was similar among new admissions and resident inmates (30.1\% versus $27.5 \%$ ). While a greater proportion of women than men accepted testing for HCV at admission, a higher proportion of men were tested in the resident population (Table 1 ).

During 2002, 483 new seropositive HCV cases were recorded, $53 \%$ of which were in resident inmates. Approximately $10 \%$ of new admissions and $7 \%$ of resident inmates were HCVseropositive. Women represented a significantly higher proportion of all positive HCV tests for new admissions than men.

The seroprevalence rate of $\mathrm{HCV}$ at year-end was $26.1 \%$, with a significantly higher prevalence rate among female inmates than male inmates. The proportion of HCV-positive inmates varied markedly by region, ranging from $18.1 \%$ in the Quebec region to $37.1 \%$ in the Pacific region, taking into account both sexes (Figure 1).

\section{DISCUSSION}

The relevance and need for expanding HIV and HCV testing The voluntary nature of HIV and HCV testing in federal prisons, coupled with the fact that not all inmates are indicated for testing, partly accounts for the apparently low rates of testing uptake. Suboptimal rates of testing in those at risk would suggest that many potential HIV and HCV-infected inmates continue to be undetected and unexposed to treatment. An effective testing program would allow inmates to determine

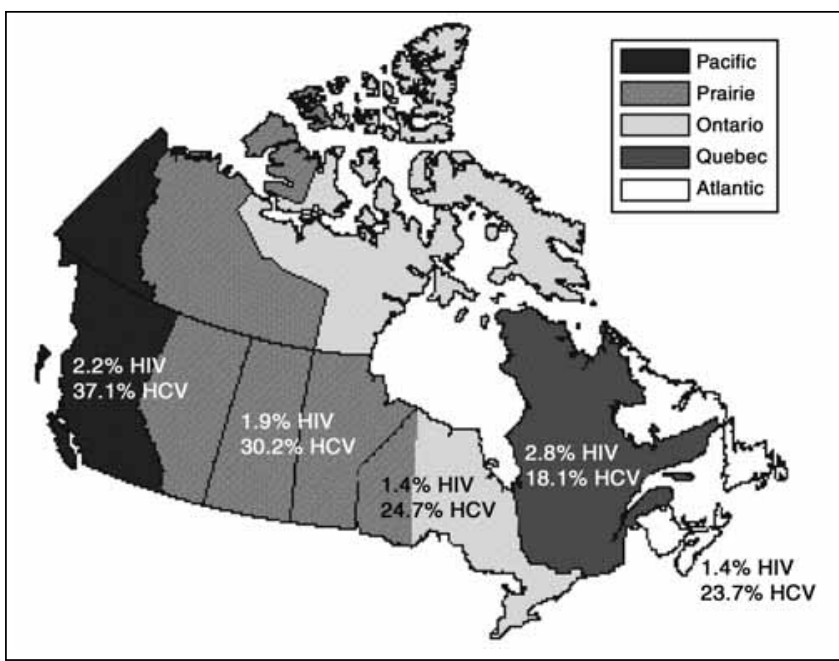

Figure 1) Estimated prevalence proportion of HIV and hepatitis $C$ virus (HCV) among federal inmates, by administrative regions of the Correctional Service of Canada, 2002

their infection status, while establishing their contact with health care. Inmates who test negative can be encouraged to practice preventive measures to remain virus-free, while those found newly positive can receive early treatment and support. Counselling for inmates during health care visits provides an important opportunity to promote harm reduction practices to individuals who may otherwise be elusive to health care services in the community. In addition, exposure to health care raises awareness of available prevention programs among inmates within the correctional system and to usher soon-to-be released inmates to community-based intervention programs. The lengthier correctional sentences served in federal prisons 
compared with provincial short-stay prisons can provide the additional benefit of not only initiating, but also maintaining, treatment for HIV, HCV and opiate addiction.

The promotion of testing through special initiatives in different institutions may account for some variation observed across regions. However, the majority of the discrepancy is likely due to regional or institutional-level differences in the emphasis placed on infection control, which, in turn, depends on the regional prevalence of disease and risk for infection among incarcerated persons.

\section{Monitoring HIV and HCV seropositivity in inmates}

Our findings are similar to seroprevalence estimates reported in previous Canadian prison studies, in which rates have ranged from $1 \%$ to $8 \%$ for HIV and $25 \%$ to $40 \%$ for HCV (15-21). A recent review (22) of international prison literature shows that the observed seroprevalence rates in the present study are comparable for HCV but differ substantially for HIV in relation to other countries. Differential infection rates of HIV compared with HCV are accounted for by biological differences between the two viruses, such as higher transmissibility and viability of HCV compared with HIV (23). The current findings also highlight the variability in inmate seropositivity for both HIV and HCV across regions in Canada, prompting a need for differential approaches to address the regional differences in morbidity. Notwithstanding the direct relation of infection rates to rates of testing uptake, this finding likely reflects regional differences in disease prevalence in the community and, by consequence, in prisons.

In 2002, female inmates represented $3 \%$ of the federal incarcerated population yet comprised $26 \%$ of all new seropositive tests for HIV and nearly $8 \%$ for HCV. The high seroprevalence of HIV and HCV among women offenders corroborates with previous findings $(16,17)$. The risk profile of incarcerated women described in other studies suggests that a greater proportion of women than men are characterized by injection drug use and prostitution before imprisonment $(6,16,17)$. However, as a result of more frequent contact with health care services for routine gynecological care, women offenders are afforded greater opportunities for disease testing compared with their male counterparts. The differential frequency of HIV and HCV testing between men and women in the present study was particularly evident in testing uptake upon admission. The higher rate of testing upon admission compared with testing during later incarceration can help in the identification of infection.

The high rates of prevalent infection identified upon admission suggests that many newly diagnosed infections are acquired before incarceration, rather than as a consequence of differential testing uptake between new admissions and resident inmates. This hypothesis is supported by a review of prisons in the United States (1) in which the authors posited that most offenders enter the correctional system with existing HIV infection and that prisons are unlikely to amplify the acquisition of infection. The contribution of incarceration to infection acquisition, whether from a current or previous sentence, remains difficult to assess because recidivism is common and the point of seroconversion cannot be accurately defined. While the current study does not demonstrate that new infections are acquired in prison, it highlights the complexity of distinguishing between different sources of infection, particularly when the period between exposure to a virus and seroconversion encompasses time in the community and in prison.

\section{Limitations}

The findings in this study are subject to several limitations. First, the inability to distinguish between first time and repeat testers because the aggregate nature of the data could artificially increase the observed testing uptake rate while lowering seropositivity rates. However, the relatively short study period of one year minimizes the possibility of duplicate testing. Second, over the course of the study period, it is possible for an inmate to be enumerated as part of both the new admission and resident populations. This would overestimate the at-risk resident population and lead to an underestimate of testing and seropositivity rates for resident inmates. It is worthy to note that the study population likely overestimates the population at risk because some resident and newly admitted offenders would not be recommended for HIV and HCV testing. Third, selfselection factors can lead to biased testing patterns, whereby those who refused testing may be more likely to test positive than voluntary testers (24). In the absence of data on the untested population, we are unable to comment on the extent to which sampling bias may have affected our results. The findings in this report are representative of inmates who have come forward for testing. However, unlike many studies which have examined samples of inmates in selected institutions, our findings provide a system-wide depiction of HIV and HCV rates in Canadian penitentiaries, albeit in a self-selected subgroup of those incarcerated.

\section{Implications}

Despite the above limitations, the results have several implications for testing, provision of preventive services and monitoring of bloodborne infections. Expanding diagnostic and treatment services is merely a first step in addressing infectious diseases in penitentiaries. A major challenge faced by correctional health care providers is the need to balance individual inmate rights with the health and safety of the wider inmate population. Ensuring that services are provided in a confidential and reassuring environment can help encourage voluntary testing and self-referral of contacts. The present study emphasizes efforts for detection of prevalent infection early in the course of an inmate's incarceration, a time when inmates may be more willing to accept testing. Prevention programs can benefit from closer integration with community-based organizations and be better tailored to meet the unique needs of vulnerable groups such as women offenders. Efforts aimed at reducing the impact of HIV infection must heed to all aspects of potential HIV transmission, and not merely focus on drug use. This includes an active campaign to reduce other sexually transmitted infections along with the sexual transmission of HIV. Such an effort would complement the existing array of preventive strategies in federal penitentiaries, which include ongoing education on infectious diseases for offenders and staff, the availability of condoms and dental dams for the prevention of sexually transmitted infections, immunization against hepatitis $\mathrm{A}$ and $\mathrm{B}$, the provision of disinfecting bleach, and a methadone maintenance treatment program for opiateaddicted inmates. A review of syringe exchange programs in several European prisons has indicated the beneficial effects in 
reducing the harm associated with needle-sharing while preventing new injection-associated infections (25). Data from similar evaluations in Canada can provide a basis for the future consideration of needle exchange strategies in federal penitentiaries. With regard to disease monitoring, it will be important to determine factors predicting the observed distribution of infection in inmates. The continued evaluation of seropositivity and testing uptake rates will allow correctional health care workers to be alerted of deficiencies in existing prevention programs and to identify segments of the incarcerated population in which promotion of testing for HIV and HCV can be improved.

\section{REFERENCES}

1. Spaulding A, Stephenson B, Macalino G, Ruby W, Clarke JG, Flanigan TP. Human immunodeficiency virus in correctional facilities: A review. Clin Infect Dis 2002;35:305-12.

2. Rotily M, Weilandt C, Bird SM, et al. Surveillance of HIV infection and related risk behaviour in European prisons. A multicentre pilot study. Eur J Public Health 2001;11:243-50.

3. Long J, Allwright S, Barry J, et al. Prevalence of antibodies to hepatitis $\mathrm{B}$, hepatitis $\mathrm{C}$, and HIV and risk factors in entrants to Irish prisons: A national cross sectional survey. BMJ 2001;323:1209-13.

4. Crofts N, Stewart T, Hearne P, Ping XY, Breschkin AM, Locarnini SA. Spread of bloodborne viruses among Australian prison entrants. BMJ 1995;310:285-8.

5. Power KG, Markova I, Rowlands A, McKee J, Anslow PJ, Killfedder C. Intravenous drug use and HIV transmission among inmates in Scottish prisons. Br J Addict 1992;87:37-45.

6. Miranda AE, Vargas PM, St Louis ME, Viana MC. Sexually transmitted diseases among female prisoners in Brazil: Prevalence and risk factors. Sex Transm Dis 2000;27:491-5.

7. Weild AR, Gill ON, Bennett D, Livingstone SJ, Parry JV, Curran L. Prevalence of HIV, hepatitis B, and hepatitis C antibodies in prisoners in England and Wales: A national survey. Commun Dis Public Health 2000;3:121-6.

8. Holsen DS, Harthug S, Myrmel H. Prevalence of antibodies to hepatitis $\mathrm{C}$ virus and association with intravenous drug abuse and tattooing in a national prison in Norway. Eur J Clin Microbiol Infect Dis 1993;12:673-6.

9. Koulierakis G, Gnardellis C, Agrafiotis D, Power KG. HIV risk behaviour correlates among injecting drug users in Greek prisons. Addiction 2000;95:1207-16.

10. O'Sullivan BG, Levy MH, Dolan KA, et al. Hepatitis C transmission and HIV post-exposure prophylaxis after needle- and syringe-sharing in Australian prisons. Med J Aust 2003;178:546-9.

11. Geduld J, Archibald CP. National trends of AIDS and HIV in Canada. Can Commun Dis Rep 2000;26:193-201.

12. Zou S, Tepper M, El Saadany S. Prediction of hepatitis C burden in Canada. Can J Gastroenterol 2000;14:575-80.

13. Calzavara LM, Burchell AN, Schlossberg J, et al. Prior opiate injection and incarceration history predict injection drug use among inmates. Addiction 2003;98:1257-65.

\section{CONCLUSION}

The relatively low testing uptake in an environment of high seropositivity stresses the significance of monitoring trends of HIV and HCV infection. Further investigation is needed to assess the reasons for refusal of testing by inmates, the contribution of various risk factors to patterns of testing uptake and to seropositivity. A priority for the control of HIV and HCV in federal inmates will be to broaden our understanding of their epidemiology through more acute surveillance. In turn, this approach can aid in evaluating current and future strategies for inmate care and for harm reduction within the prison environment.

14. Guimaraes T, Granato CF, Varella D, Ferraz ML, Castelo A, Kallas EG. High prevalence of hepatitis C infection in a Brazilian prison: Identification of risk factors for infection. Braz J Infect Dis 2001;5:111-8.

15. Ford PM, Pearson M, Sankar-Mistry P, Stevenson T, Bell D, Austin J. HIV, hepatitis C and risk behaviour in a Canadian medium-security federal penitentiary. QJM 2000;93:113-9.

16. Hankins C, Gendron S, Richard C, O'Shaughnessy M. HIV-1 infection in a medium security prison for women - Quebec. Can Dis Wkly Rep 1989;15:168-70.

17. Ford PM, White C, Kaufmann H, et al. Voluntary anonymous linked study of the prevalence of HIV infection and hepatitis C among inmates in a Canadian federal penitentiary for women. CMAJ 1995;153:1605-9.

18. Prefontaine RG, Chaudhary RK, Mathias RG. Analysis of risk factors associated with hepatitis B and C infection in correctional institutions in British Columbia. Can J Infect Dis 1994;5:153-6.

19. Calzavara LM, Major C, Myers T, et al. The prevalence of HIV-1 infection among inmates in Ontario, Canada. Can J Public Health 1995;86:335-9.

20. Rothon DA, Mathias RG, Schechter MT. Prevalence of HIV infection in provincial prisons in British Columbia. CMAJ 1994;151:781-87.

21. Dufour A, Alary M, Poulin C, et al. Prevalence and risk behaviours for HIV infection among inmates of a provincial prison in Quebec City. AIDS 1996;10:1009-15.

22. Macalino GE, Hou JC, Kumar MS, Taylor LE, Sumantera IG, Rich JD. Hepatitis C infection and incarcerated populations. Int J Drug Policy 2004;15:103-14.

23. Heintges T, Wands JR. Hepatitis C virus: Epidemiology and transmission. Hepatology 1997;26:521-6.

24. Behrendt C, Kendig N, Dambita C, Horman J, Lawlor J, Vlahov D. Voluntary testing for human immunodeficiency virus (HIV) in a prison population with a high prevalence of HIV. Am J Epidemiol 1994;139:918-26.

25. Dolan K, Rutter S, Wodak AD. Prison-based syringe exchange programmes: A review of international research and development. Addiction 2003;98:153-8. 


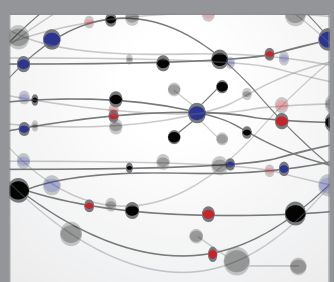

The Scientific World Journal
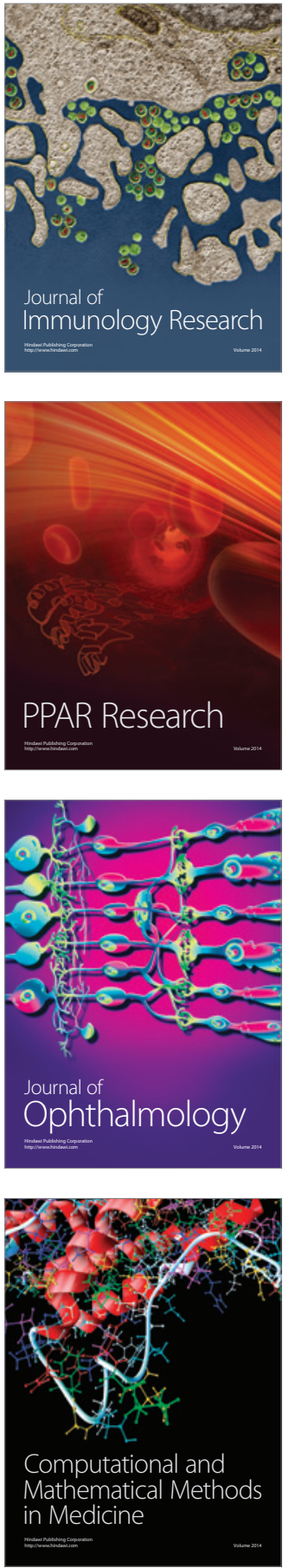

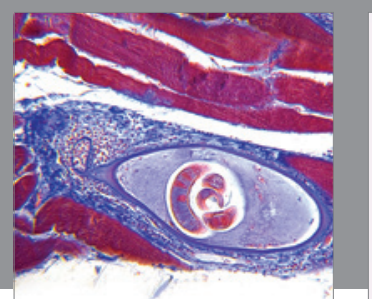

Gastroenterology Research and Practice

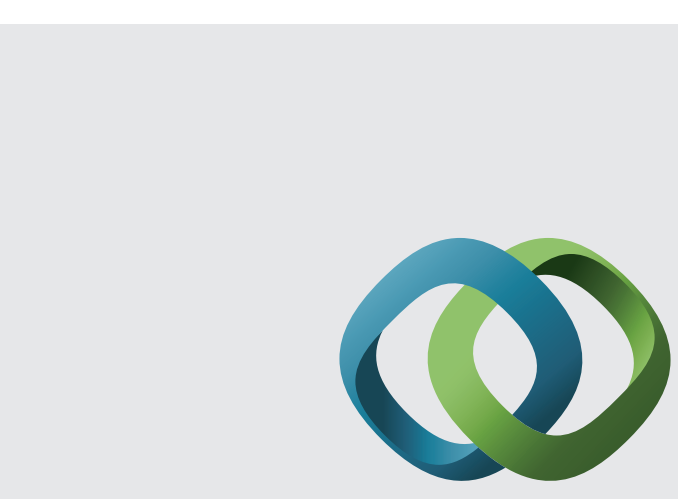

\section{Hindawi}

Submit your manuscripts at

http://www.hindawi.com
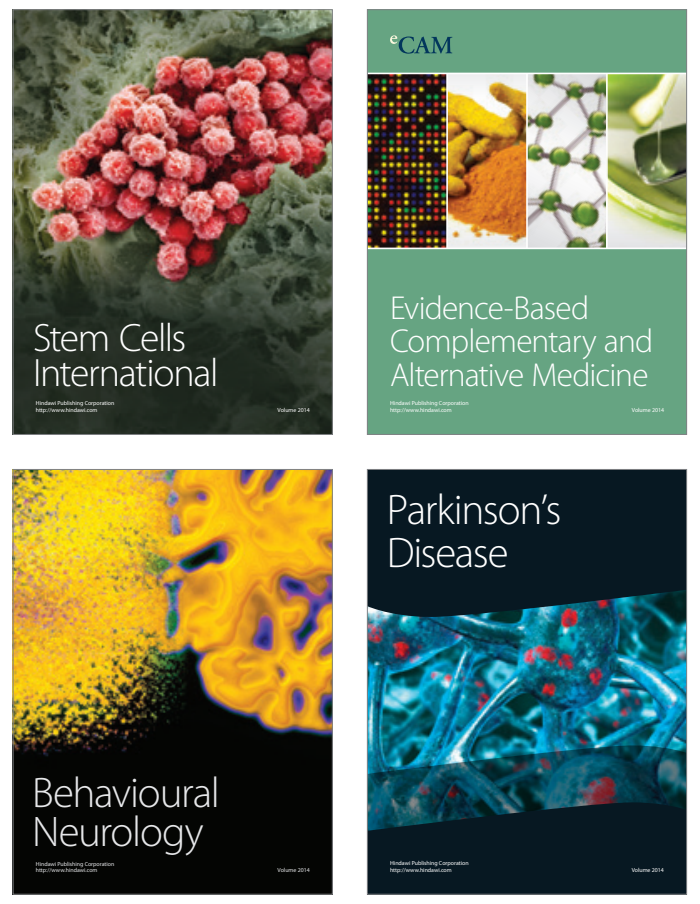
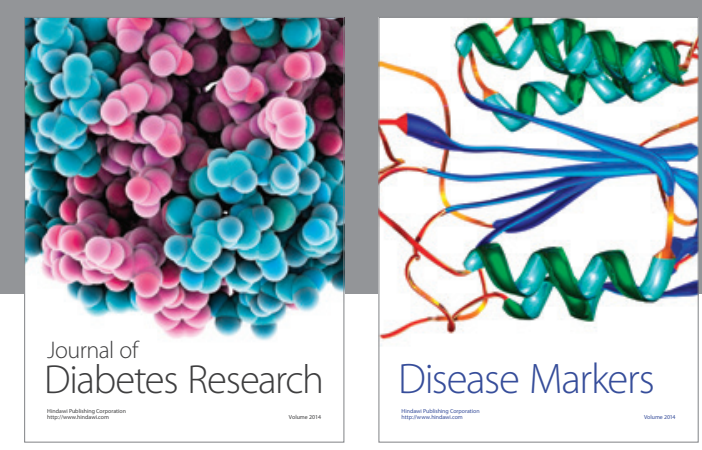

Disease Markers
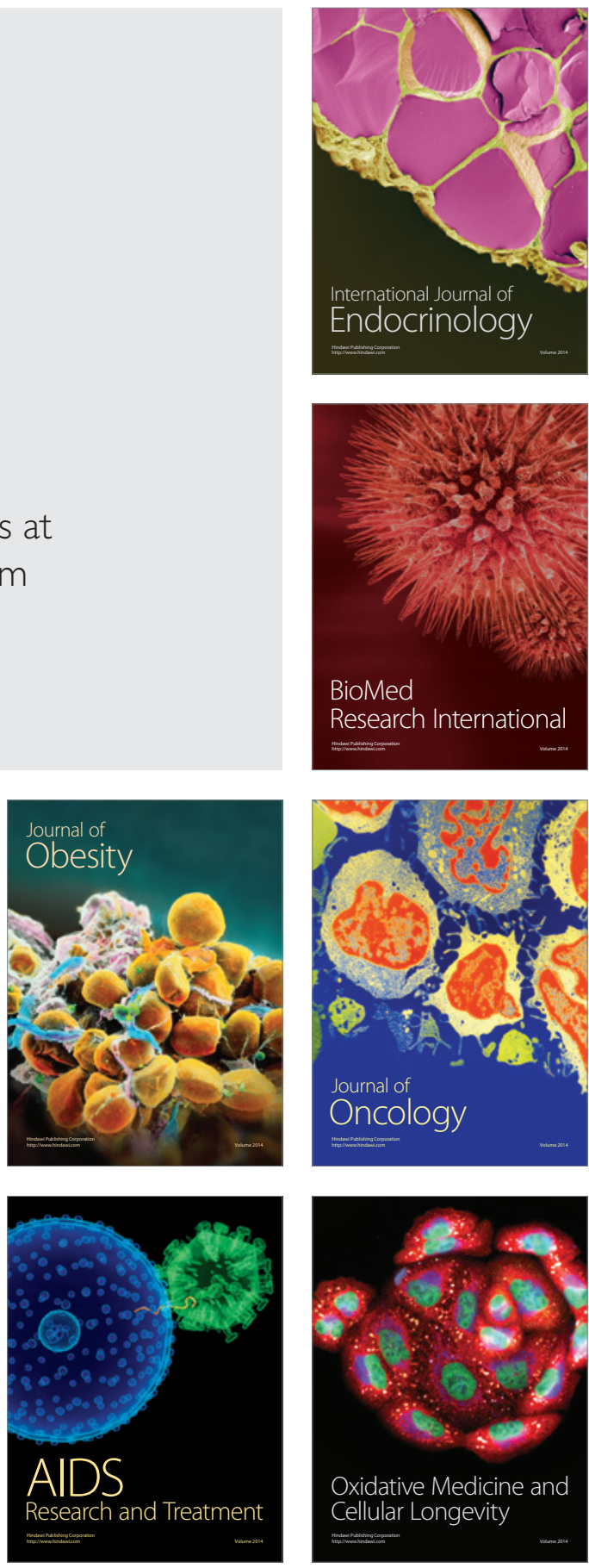